\title{
Therapeutic Use of Hyaluronidase in Obstetrics
}

\author{
Dana Sawan ${ }^{1,2 *}$, Barbara Hersant ${ }^{1}$ \\ ${ }^{1}$ Department of Plastic, Reconstructive, Aesthetic and Maxillo-Facial Surgery, Henri Mondor University Hospital, Créteil, France \\ ${ }^{2}$ Department of Obstetrics and Gynaecology, Faculty of Medicine, King Abdulaziz University, Jeddah, Saudi Arabia \\ Email: *dsawan@kau.edu.sa
}

How to cite this paper: Sawan, D. and Hersant, B. (2021) Therapeutic Use of Hyaluronidase in Obstetrics. Open Journal of Obstetrics and Gynecology, 11, 1581-1588. https://doi.org/10.4236/ojog.2021.1111147

Received: October 5, 2021

Accepted: November 20, 2021

Published: November 23, 2021

Copyright (c) 2021 by author(s) and Scientific Research Publishing Inc. This work is licensed under the Creative Commons Attribution International License (CC BY 4.0).

http://creativecommons.org/licenses/by/4.0/

\begin{abstract}
Introduction: Hyaluronidases are a group of enzymes that permit greater diffusion of fluid through the tissues. These enzymes have the ability to reduce the viscosity of hyaluronic acid and increase cellular membrane and blood vessel permeability. This review discusses the indication, usage, effects, and safety of hyaluronidases in obstetrics. Materials and Methods: MEDLINE/ PubMed and the Cochrane Library were searched using the following terms: ("hyaluronidase" [Title/Abstract]) OR ("hyaluronidases" [Title/Abstract]) AND ("therapeutic use" [Title/Abstract]) OR ("therapeutic uses" [Title/Abstract]) OR ("perineal trauma" [Title/Abstract]) OR ("perineal tear" [Title/Abstract]) OR ("cervical ripening" [Title/Abstract]). Results: This review included four randomized controlled trials (RCT) that randomized a total of 642 pregnant women and two interventional non-RCTs that included a total of 2824 pregnant women. The data from two RCTs suggested that the incidence of perineal trauma was significantly lower in the intervention (perineal hyaluronidase injection in stage two of labor) than the control group (no intervention). However, both groups did not differ significantly in the incidence of firstand second-degree tears. Similarly, no significant difference in the incidence of episiotomy was found between both groups. In one interventional non-RCT, the administration of intracervical hyaluronidase was associated with a statistically significant acceleration and shortening of labor by approximately 1.95 hours after the injection of intracervical hyaluronidase. However, it had no effect on uterine contractions or the duration of stages two and three labor. Conclusions: While it is safe, clinicians should consider patient acceptance and the effectiveness of hyaluronidase compared to conventional less invasive methods.
\end{abstract}

\section{Keywords}

Hyaluronidase, Cervical Ripening, Perineal Tear, Perineal Trauma, Hyaluronic Acid, Episiotomy 


\section{Introduction}

Hyaluronidases are a group of enzymes that degrade hyaluronic acid, a basic component of the extracellular matrix. These enzymes have the ability to cause transient relaxation of connective tissue by depolymerizing and hydrolyzing hyaluronic acid, which is a glycosaminoglycan found in several tissues, including connective, epithelial, and neural tissues. Hyaluronidase has been widely employed in several branches of medicine, including esthetic medicine [1], reproductive medicine [2], oncology [3], obstetrics [4] [5] [6], and anesthetics [7].

This review discusses the indication, usage, effects, and complications of hyaluronidases in medicine, with a focus on its therapeutic uses in obstetrics.

\section{Materials and Methods}

MEDLINE/PubMed and the Cochrane Library were searched using the following terms: ("hyaluronidase" [Title/Abstract]) OR ("hyaluronidases" [Title/Abstract]) AND ("therapeutic use" [Title/Abstract]) OR ("therapeutic uses" [Title/Abstract]) OR ("perineal trauma” [Title/Abstract]) OR ("perineal tear" [Title/Abstract]) OR ("cervical ripening" [Title/Abstract]). An overview of the process is outlined in Figure 1.
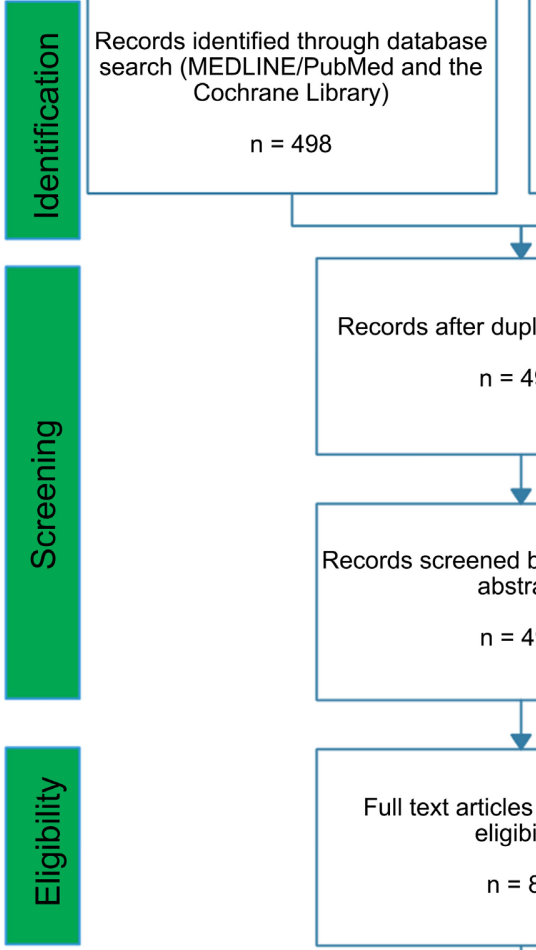

Additional records identified through other sources

$$
n=13
$$
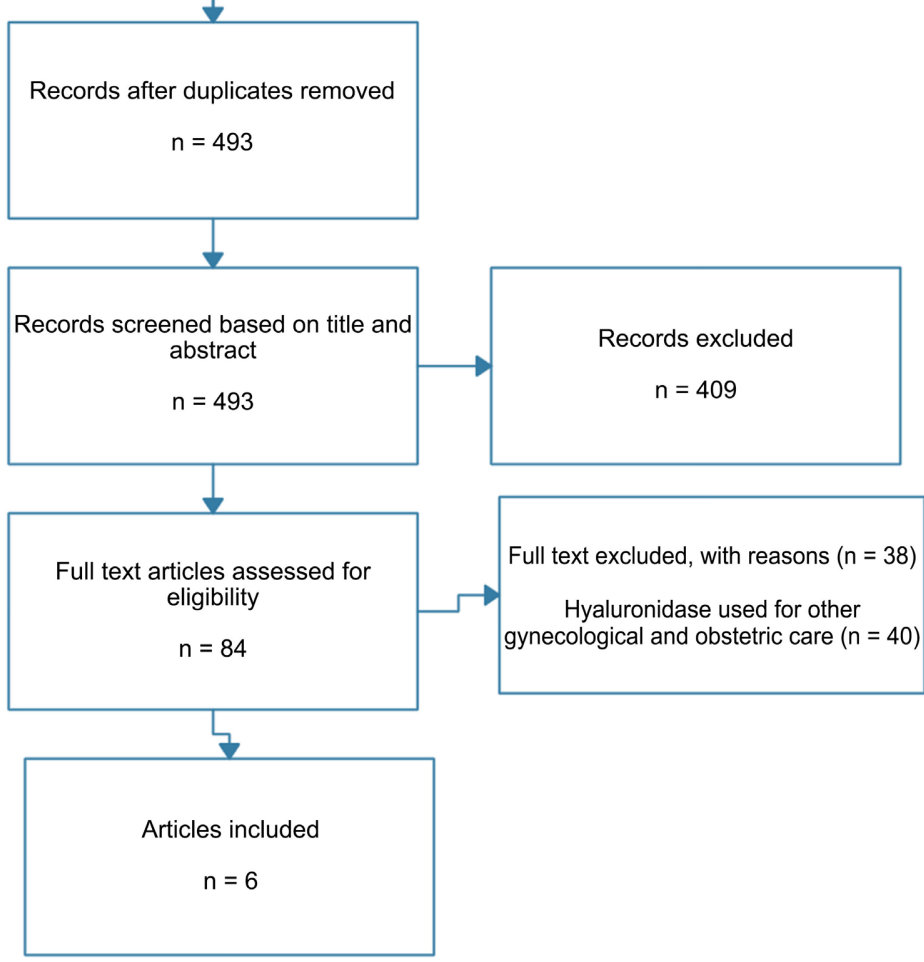

Figure 1. Flow chart illustrating the process of article selection and rejection. 


\section{Results}

The search strategy identified 84 potentially eligible studies. Thirty-eight studies were excluded because hyaluronidase was used for other gynecological and obstetric care, and 40 were excluded for a variety of reasons.

This review included four randomized controlled trials (RCT) that randomized a total of 642 pregnant women and two interventional non-RCTs that included a total of 2824 pregnant women. Table 1 shows the characteristics of the included studies.

Two RCTs [5] [6] (328 women) compared the effects of perineal hyaluronidase injection versus placebo during stage two of labor. Conversely, two RCTs [8] [9] (239 women) compared the effects of perineal hyaluronidase versus no intervention during stage two of labor. One interventional study [10] compared the effects of intracervical hyaluronidase injection versus no intervention. Finally, another interventional study [11] investigated the effects of hyaluronidase and ergometrine (both administered intramuscularly) in three groups of women: hyaluronidase $1 \mathrm{mg}$ plus ergometrine $0.25 \mathrm{mg}$ (254 women), hyaluronidase $1 \mathrm{mg}$ plus ergometrine $0.5 \mathrm{mg}$ (1748 women), and ergometrine $0.5 \mathrm{mg}$ alone (747 women).

\subsection{Hyaluronidase versus Placebo}

Two RCTs compared the effects of hyaluronidase versus placebo [5] [6]. One RCT did not find significant differences in the incidence of perineal trauma between women receiving perineal hyaluronidase injection and those receiving a placebo injection during stage two of labor [5]. Both groups did not also differ significantly on the incidence of first-, second-, third-, or fourth-degree tears. Additionally, the investigators did not find significant differences in the incidence of episiotomy between the intervention and placebo groups.

The other RCT did not report on the incidence of perineal trauma or episiotomy [6]. Rather, the investigators found that the average duration of labor was significantly decreased in the group receiving intracervical hyaluronidase compared to the placebo group.

None of the RCTs investigated the adverse effects associated with the administration of hyaluronidase.

\subsection{Hyaluronidase versus No Intervention}

Three studies, including two RCTs [8] [9] and one interventional non-RCT [10], compared the effects of hyaluronidase versus no intervention. In the RCTs, the incidence of perineal trauma was significantly lower in the intervention (perineal hyaluronidase injection in stage two of labor) than the control group (no intervention) [8] [9]. However, in one report [8], both groups did not differ significantly in the incidence of first- and second-degree tears. Similarly, the investigators found no significant difference in the incidence of episiotomy between both groups. The incidence of third- and fourth-degree tears was not reported in the 
Table 1. Characteristics of the included studies.

\begin{tabular}{|c|c|c|c|c|c|}
\hline Author & $\begin{array}{l}\text { Number of } \\
\text { Cases }\end{array}$ & Study Design & $\begin{array}{c}\text { Injection Site/ } \\
\text { Administration } \\
\text { Mode }\end{array}$ & HA Dose & Results \\
\hline $\begin{array}{l}\text { Colacioppo et } \\
\text { al. [5] }\end{array}$ & $\begin{array}{l}160 \text { ( } 80 \text { in the } \\
\text { experimental } \\
\text { and } 80 \text { in the } \\
\text { placebo group) }\end{array}$ & RCT & $\begin{array}{l}\text { Posterior region } \\
\text { of the perineum }\end{array}$ & $\begin{array}{l}-20.000 \text { turbidity- } \\
\text { reducing units } \\
(5 \mathrm{~mL})\end{array}$ & $\begin{array}{l}\text { - No difference in the incidence of perineal } \\
\text { trauma between both groups } \\
\text { - No difference in the incidence of first-, second-, } \\
\text { third-, or fourth-degree tears between both } \\
\text { groups } \\
\text { - No difference in the incidence of episiotomy } \\
\text { between both groups }\end{array}$ \\
\hline $\begin{array}{l}\text { Spallicci et al. } \\
\text { [6] }\end{array}$ & $\begin{array}{l}168 \text { ( } 83 \text { in the } \\
\text { experimental } \\
\text { group and } 85 \text { in } \\
\text { the placebo } \\
\text { group) }\end{array}$ & RCT & Cervix & $\begin{array}{l}\text { - 20,000 UI of } \\
\text { lyophilized HA } \\
(5 \mathrm{~mL})\end{array}$ & $\begin{array}{l}\text { - Significant decrease in the average duration of } \\
\text { labor in the experimental group }\end{array}$ \\
\hline $\begin{array}{l}\text { O'Leary et al. } \\
\qquad 8]\end{array}$ & $\begin{array}{l}100 \text { (50 each in } \\
\text { the experimental } \\
\text { and control } \\
\text { groups) }\end{array}$ & $\begin{array}{l}\text { RCT (2-arm } \\
\text { design with } \\
\text { randomized } \\
\text { selection) }\end{array}$ & $\begin{array}{l}\text { Perineal body, } \\
\text { hymen, and any } \\
\text { previous } \\
\text { episiotomy scars }\end{array}$ & $\begin{array}{c}5 \text { - } 10 \text { mL HA } \\
\text { (contained } \\
750 \text { - } 1550 \\
\text { turbidity-reducing } \\
\text { units of HA) }\end{array}$ & $\begin{array}{l}\text { - Lower incidence of perineal trauma in the } \\
\text { experimental group } \\
\text { - No difference in the incidence of episiotomy } \\
\text { between the groups } \\
\text { - No difference in the incidence of first- and } \\
\text { second-degree perineal trauma between both } \\
\text { groups } \\
\text { - No side effects }\end{array}$ \\
\hline $\begin{array}{c}\text { Scarabotto } \\
\text { and Riesco [9] }\end{array}$ & $\begin{array}{l}139 \text { (71 in the } \\
\text { intervention and } \\
68 \text { in the control } \\
\text { group) }\end{array}$ & RCT & $\begin{array}{l}\text { Posterior region } \\
\text { of the perineum }\end{array}$ & $\begin{array}{c}5 \text { mL HA }(20,000 \\
\text { turbidity-reducing } \\
\text { unit })\end{array}$ & $\begin{array}{l}\text { - Significant differences in the frequency of } \\
\text { perineal trauma ( } 39.4 \% \text { in the intervention } \\
\text { group vs } 76.5 \% \text { in controls) } \\
\text { - Significant differences in the degree of } \\
\text { spontaneous laceration ( } 0.0 \% \text { in the } \\
\text { intervention group vs } 82.4 \% \text { in controls) } \\
\text { - Significant differences in the frequency of } \\
\text { lacerations in the posterior perineum ( } 54.2 \% \text { in } \\
\text { the intervention group vs } 84.3 \% \text { in controls) } \\
\text { - No difference in the incidence of episiotomy } \\
\text { between the groups } \\
\text { - No side effects }\end{array}$ \\
\hline $\begin{array}{l}\text { Gupta et al. } \\
\quad[10]\end{array}$ & $\begin{array}{l}75 \text { (50 in the } \\
\text { experimental } \\
\text { and } 25 \text { in the } \\
\text { control group) }\end{array}$ & Interventional & Cervix & $\begin{array}{c}20,000 \mathrm{UI} \\
\text { lyophilized HA }\end{array}$ & $\begin{array}{l}\text { - Labor was accelerated and shortened by an } \\
\text { average of } 1.95 \text { hours in the experimental group } \\
\text { - Cervical dilation rate was increased in the } \\
\text { experimental group } \\
\text { - No effect on uterine contractions in both } \\
\text { groups } \\
\text { - No cervical tears in both groups }\end{array}$ \\
\hline Kimbell [11] & $\begin{array}{l}2749 \text { (2002 in } \\
\text { the experimental } \\
\text { and } 747 \text { in the } \\
\text { control group) }\end{array}$ & Interventional & Intramuscular & $\begin{array}{l}0.5 \mathrm{mg} \text { EM alone } \\
(\mathrm{n}=198), 0.25 \mathrm{mg} \\
\mathrm{EM}+\text { HA } 1 \mathrm{mg} \\
(\mathrm{n}=254) \text {, and } 0.5 \\
\mathrm{mg} \mathrm{EM}+\text { HA } 1 \mathrm{mg} \\
\quad(\mathrm{n}=1748)\end{array}$ & $\begin{array}{l}\text { Post-partum hemorrhage rate decreased in the } \\
\text { experimental group ( } 0.9 \% \text { vs } 6.4 \% \text { in controls) } \\
\text { - Manual placenta removal rate was not } \\
\text { appreciably influenced ( } 1.6 \% \text { in controls vs } \\
1.1 \% \text { for cases) } \\
\text { - Blood loss was lower in the experimental group } \\
\text { - Stage III labor was shortened in the } \\
\text { experimental group }\end{array}$ \\
\hline
\end{tabular}

Abbreviations: EM, ergometrine; HA, hyaluronidase; RCT, randomized controlled trial. 
trial, so no relevant conclusions can be drawn from this. In the other RCT [9], the investigators reported significant differences in the degree of spontaneous laceration ( $0.0 \%$ in the intervention group vs. $82.4 \%$ in controls) and frequency of lacerations in the posterior perineum (54.2\% in the intervention group vs $84.3 \%$ in controls). Nevertheless, the investigators found no differences between both groups when they grouped women who had an episiotomy and second-degree lacerations and excluded those with an intact perineum.

In the interventional non-RCT, the administration of intracervical hyaluronidase was associated with a statistically significant acceleration and shortening of labor by approximately 1.95 hours after the injection of intracervical hyaluronidase [10]. However, it had no effect on uterine contractions or the duration of stages two and three labor. The investigators found no incidence of cervical tear in the sample.

None of the studies investigated the adverse effects associated with hyaluronidase.

\subsection{Hyaluronidase plus Ergometrine}

The data from one interventional non-RCT showed that intramuscular hyaluronidase plus ergometrine during stage two of labor resulted in lower blood loss and shortening of stage three compared to ergometrine alone [11].

\section{Discussion}

This review included studies evaluating the effectiveness of hyaluronidase injection during labor for decreasing the incidence of spontaneous perineal trauma and episiotomy in vaginal deliveries. One of the studies, an interventional non-RCT investigated the efficacy of a combination of hyaluronidase and ergometrine versus ergometrine alone in decreasing the incidence of post-partum hemorrhage. However, hyaluronidases were used in obstetrics in the 1950s for the prevention of post-partum hemorrhage [11] and are no longer indicated for this purpose [7]. Since the 1950s, perineal hyaluronidase injection has been widely used to decrease the frequency of perineal tears, pain, and the need for episiotomy [8] [12].

Data from the studies included in this review show that the injection of hyaluronidase into the perineum during stage two of labor resulted in a significantly lower incidence of perineal trauma compared to a perineal injection of placebo. However, both groups did not differ significantly in the incidence of episiotomy as well as the incidence of first- and second-degree perineal lacerations. A systematic review conducted by Zhou et al. examined the efficacy and safety of perineal hyaluronidase injection administered in stage two of labor [4]. The investigators analyzed data from four randomized controlled trials (total of 599 women) and reported a lower incidence of perineal injury in women who received a perineal injection of hyaluronidase during the second stage of labor than in the control group (women who received perineal placebo or had no in- 
tervention) [4]. Nevertheless, women who received perineal hyaluronidase did not differ significantly from those who received placebo on the incidence of episiotomy, perineal injury, and degree of perineal tears. The investigators also found that the incidence of perineal injury was significantly lower following the administration of an injection of hyaluronidase during stage two of labor than when no treatment was offered [4]. However, the incidence of episiotomy and degree of tears (first and second) did not differ significantly between both groups (hyaluronidase administration versus no intervention). Overall, the analyses suggested that perineal injection of hyaluronidase was safe and appeared to be a potential method of decreasing perineal tears [4].

In a previous report [9], primiparous women in labor were randomized to receive an injection of hyaluronidase in the posterior perineum or no treatment during the second stage of labor. The intervention resulted in a lower frequency of perineal injury and lower severity of perineal lacerations, especially in women who did not have an episiotomy. Of note is the fact that all the women in the study were primiparous, and perineal tears were less frequent in the intervention group, which highlights the potential efficacy of hyaluronidase in preventing perineal tears and, consequently, improving gestational outcomes. The investigators suggested that the administration of hyaluronidase in the posterior perineum might potentially protect surrounding tissues because most of the spontaneous perineal tears in the intervention group occurred in the anterior perineum. Their hypothesis was further supported by the fact that women in the intervention group did not experience second-degree tears.

Hyaluronidase may be injected intracervically to cause cervical ripening and shorter duration of labor. There is no recommended dose for this indication, but in one of the studies included in this review, women received 20,000 UI lyophylizated hyaluronidase (in $5 \mathrm{~mL}$ distilled water) [6]. One dose of $2.5 \mathrm{~mL}$ was injected into the upper cervix and an equivalent amount was injected into the lower cervix. Improving cervical dilatation can help shorten the labor duration and, consequently, decrease the need for drugs and sedation, which will be beneficial for the neonate. Because traditional methods for cervical ripening (dinoprostone and misoprostol administration) have been reported to cause uterine contractile abnormalities, researchers have investigated more efficient methods to increase the Bishop score to increase the chances of vaginal delivery. Reports from studies conducted in the early 1990s showed that the injection of hyaluronidase in the cervix was associated with an improvement in cervical ripening and a decrease in labor duration [10] [13] [14]. Spallicci et al. [6] achieved an increase in the Bishop score to $>5$ after 96 hours in $93 \%$ of the women who received an injection of hyaluronidase into the cervix; a much smaller proportion of women in the placebo group (17\%) had an increased Bishop score. While the Bishop score subsequently increased in both groups, the rate of increase was higher in the intervention group, suggesting that hyaluronidase was effective in causing cervical ripening [6]. 
Spallicci et al. [6] also found that, when compared with placebo, an intracervical injection of hyaluronidase was significantly associated with a lower rate of cesarean sections. Women who received intracervical hyaluronidase were less likely than those who received placebo to need oxytocin augmentation to progress labor. Intracervical injection of hyaluronidase was also significantly associated with increased cervical favorability after 24 hours and was not associated with adverse events in the mother or the newborn [6]. Although these findings suggest that hyaluronidase is beneficial in causing cervical ripening and shortening the duration of labor, there is no evidence of its effect on labor induction. Furthermore, hyaluronidase is invasive and might not be accepted by some women.

The limitations of this review cannot be overlooked. First, our search was restricted to major databases, and some potential studies may have consequently been missed. Second, only articles published in English were included. Third, we did not attempt to identify or minimize potential biases during the review process. Finally, we did not assess the quality of included studies.

\section{Conclusion}

Hyaluronidases may be beneficial in obstetric practice. However, studies are still being conducted to confirm the effectiveness of the enzyme in causing cervical ripening, preventing perineal trauma, and shortening labor duration. While it is safe, clinicians should consider patient acceptance and the effectiveness of the drug compared to conventional less invasive methods.

\section{Conflicts of Interest}

The authors declare no conflicts of interest regarding the publication of this paper.

\section{References}

[1] Baring, D.E.C. and Marshall, J.N. (2011) How We Do It: Hyaluronidase Injection for the Rhinoplasty Patient. Clinical Otolaryngology, 36, 588-589. https://doi.org/10.1111/j.1749-4486.2011.02397.x

[2] Evison, M., Pretty, C., Taylor, E. and Franklin, C. (2009) Human Recombinant Hyaluronidase (Cumulase) Improves Intracytoplasmic Sperm Injection Survival and Fertilization Rates. Reproductive BioMedicine Online, 18, 811-814. https://doi.org/10.1016/S1472-6483(10)60030-2

[3] Kohno, N., Ohnuma, T. and Truog, P. (1994) Effects of Hyaluronidase on Doxorubicin Penetration into Squamous Carcinoma Multicellular Tumor Spheroids and Its Cell Lethality. Journal of Cancer Research and Clinical Oncology, 120, 293-297. https://doi.org/10.1007/BF01236386

[4] Zhou, F., Wang, X.D., Li, J., Huang, G.Q. and Gao, B.X. (2014) Hyaluronidase for Reducing Perineal Trauma. Cochrane Database Syst Rev, No. 2, CD010441. https://doi.org/10.1002/14651858.CD010441.pub2

[5] Colacioppo, P.M., Gonzalez Riesco, M.L. and Koiffman, M.D. (2011) Use of Hyaluronidase to Prevent Perineal Trauma during Spontaneous Births: A Randomized, 
Placebo-Controlled, Double-Blind, Clinical Trial. Journal of Midwifery \& Women's Health, 56, 436-445. https://doi.org/10.1111/j.1542-2011.2011.00056.x

[6] Spallicci, M.D.B., Chiea, M.A., Singer, J.M., Albuquerque, P.B., Bittar, R.E. and Zugaib, M. (2007) Use of Hyaluronidase for Cervical Ripening: A Randomized Trial. European Journal of Obstetrics \& Gynecology and Reproductive Biology, 130, 46-50. https://doi.org/10.1016/j.ejogrb.2005.10.028

[7] Dunn, A.L., Heavner, J.E., Racz, G. and Day, M. (2010) Hyaluronidase: A Review of Approved Formulations, Indications and Off-Label Use in Chronic Pain Management. Expert Opinion on Biological Therapy, 10, 127-131. https://doi.org/10.1517/14712590903490382

[8] O'Leary, J. and Erez, S. (1965) Hyaluronidase as an Adjuvant to Episiotomy. Obstetrics \& Gynecology, 26, 66-69.

[9] Scarabotto, L.B. and Riesco, M.L.G. (2008) Use of Hyaluronidase to Prevent Perineal Trauma during Spontaneous Delivery: A Pilot Study. Journal of Midwifery \& Women's Health, 53, 353-361. https://doi.org/10.1016/j.jmwh.2008.02.015

[10] Gupta, T., Verma, N. and Sood, A. (1994) Effects of Intracervical Injection of Haase in Primigravidae during Labor. Journal of Indian Medical Association, 92, 47-48.

[11] Kimbell, N. (1954) Intramuscular Ergometrine and Hyaluronidase in Prevention of Post-Partum Haemorrhage. The BMJ, 2, 130-131. https://doi.org/10.1136/bmj.2.4880.130

[12] Mink, E. (1955) Experience with the Softening Effect of Hyaluronidase on High and Rigid Perineum in Primiparous. Geburtshilfe Frauenheilkd, 15, 246-258.

[13] Li, Z. (1993) Clinical Study on Uterine Cervix Ripening with HAase and Animal Experimentation on Mechanism of Action. Chinese Journal of Obstetrics and Gynecology, 28, 592-594.

[14] Li, W., Li, Z. and Ha, K. (1994) Effect of HAase on Cervical Ripening. Chinese Medical Journal (Engl.), 107, 552-553. 